\title{
PENGARUH KUALITAS PELAYANAN, KUALITAS PRODUK DAN KEPUASAN PELANGGAN TERHADAP RETENSI PELANGGAN STUDI KASUS ROTI BAKAR 88 PASAR LAMA TANGERANG
}

\author{
Lina Anggraini \\ linaanggraini05@gmail.com \\ Fakultas Ekonomi dan Bisnis Universitas Islam Syekh Yusuf Tangerang \\ Dr. H. Hadi Suharno, SE., MM \\ hsuharno@unis.ac.id \\ Fakultas Ekonomi dan Bisnis Universitas Islam Syekh Yusuf Tangerang \\ Umi Kulsum, SE., MM \\ ukulsum@unis.ac.id \\ Fakultas Ekonomi dan Bisnis Universitas Islam Syekh Yusuf Tangerang
}

\begin{abstract}
This research was done to analyze the effect of variable $(X I)$ quality of service to the variable $(Y)$ that is customer retention, the influence of variables $(X 2)$ is the quality of products to variable $(Y)$ that is customer retention, , the influence of variables $(X 3)$ is the customer satisfaction to variable $(Y)$ that is customer retention and the effect of variable (XI) which is variable quality Comfort, variable (X2) is the quality of the product and variabel (X3) is the customer satisfaction simultaneously to variable $(Y)$ customer retention. This research was conducted using a survey method. The population in this study is that consumers Roti Bakar 88 Pasar Lama Tangerang. Sampling with 100 respondents conducted by random sampling technique. While the analysis is done with the data, the classic assumption test hypothesis testing, validity, reliability, multiple regression analysis, multiple correlation analysis, and analysis of the coefficient of determination $\left(R^{2}\right)$. Based on data analysis performed in this study, it can be concluded that the variable $(X I)$ quality of service and significant positive effect on the variable $(Y)$ is $38 \%$ of customer retention. Variable $(X 2)$ is the product quality and significant positive effect on the variable $(Y)$ is II\% of customer retention, Variable $(X 3)$ is the customer satisfaction and significant positive effect on the variable $(Y)$ is $18 \%$ of customer retention. F-count value is greater than the value of 798,0 I F-table is 0,39 . So Ho rejected and $\mathrm{Ha}$ accepted. The rest was influenced by other variables not examined in this study.
\end{abstract}

Keywords: Quality of Service, Quality of Products, Customer Satisfaction, Customer Retention

\section{A. PENDAhUluan}

Di era globalisasi saat ini persaingan bisnis merupakan fenomena yang sangat menarik untuk diteliti, terutama di dalam bidang ekonomi. Hal ini turut membuka peluang bagi pelaku usaha untuk berkompetisi menjaring pelanggan. Perkembangan bisnis kuliner di Tanah Air dalam beberapa tahun terakhir bahkan semakin masif. Indonesia menjadi pasar potensial yang meningkat berbekal dengan populasi penduduk yang besar ditambah jumlah kelas menengah yang meningkat tajam. Gaya hidup yang tidak lepas terpengaruh dari era globalisasi ini telah banyak memengaruhi industri yang satu ini yang menjadikan kuliner bukan hanya sebuah kebutuhan. Dengan perkembangan zaman ini perusahaan di tuntut untuk bekerja keras untuk memberikan barang atau jasa yang terbaik untuk memenuhi keinginan dan kebutuhan yang sesuai dengan harapan pelanggan agar dapat mempertahankan pangsa pasarnya. Semakin rendahnya pertumbuhan pasar serta tingginya persaingan khususnya di sektor kuliner, membuat perusahaan lebih cenderung untuk berusaha mempertahankan pangsa pasar dengan berfokus pada mempertahankan pelanggan yang sudah ada. Jika perusahaan terus hanya berusaha menarik pelanggan baru untuk menggantikan pelanggan yang sudah berpindah, tidak mungkin perusahaan dapat tumbuh dan meraih pangsa pasar. Mengembangkan hubungan jangka panjang, kini memiliki nilai yang lebih baik serta dianggap sebagai metode yang lebih efektif untuk pertumbuhan perusahaan dan peningkatkan profitabilitas.

Dalam upaya mempertahankan pelanggan, perusahaan perlu berusaha untuk menciptakan loyalitas pelanggan. Namun perusahaan perlu menyadari bahwa sikap loyal saja tidak cukup untuk menjamin kelangsungan hidup perusahaan, karena sikap loyal tidak banyak mempengaruhi 
angka penjualan maupun profit. Perlu adanya tindakan nyata sebagai bukti bahwa pelanggan benarbenar loyal terhadap perusahaan, yaitu adanya customer retention. Oleh karena itu, banyak perusahaan telah menyimpulkan untuk semakin mengadaptasi teknik customer retention guna meningkatkan kinerja perusahaan.

Pada tahun 2018 Kementrian Perindustrian (Kemenperin) menyebut sektor makanan dan minuman berhasil menyumbang produk domestik bruto (PDB) nasional sebesar 6,34\% bahkan pada tahun 2019 sektor makanan dan minuman diyakini terus menjadi primadona.

Seperti di salah satu kota Tangerang ini, suatu daerah atau kota menjadi faktor penting dalam perkenomian daerah atau kota itu sendiri, sehingga persaingan bagi setiap perusahaan penyedia barang atau jasa dan masyarakat berusaha untuk mendapatkan ekonomi yang lebih baik melalui perkembangan pecinta kuliner. Roti bakar 88 menjadi salah satu bisnis kuliner yang berkembang di Tangerang. Roti bakar 88 selalu melakukan inovasi serta promosi guna meningkatkan daya saing. Dalam melakukan pemasarannya Roti Bakar 88 menerapkan marketing mix. Pengembangan penjualan disesuaikan dengan kebutuhan atau selera konsumen. Kemudian dalam mempertahankan konsumen, pihak pengusaha kuliner harus mampu menumbuhkan daya tarik pada produknya, sehingga pelanggan dapat kembali lagi untuk membeli produk.

Pemilik Roti bakar 88 mengembangkan bisnis ini pada tahun 2002. Pemilik memang telah merencanakan untuk membangun bisnis mandiri dengan target yakni bisnis kuliner. Setelah memantau potensi bisnis kuliner di wilayah tempat tinggalnya yakni di Tangerang, Banten. Dalam hal persaingan bisnis, pemilik roti bakar 88 tahu betul bahwa hal tersebut adalah kepastian yang selalu ada dan tidak bisa dihindari saat menjalankan sebuah bisnis. Bahkan sejak awal mendirikan usaha, ia sudah mulai memprediksi tentang strategi persaingan dengan kompetitor bisnisnya. Strategi pemasaran secara lebih rinci dikaitkan dengan berbagai unsur, seperti dalam kaitannya dengan kualitas pelayanan, kualitas produk, kepuasan pelanggan ataupun dengan analisis faktor retensi pelanggan. Dalam penulisan skripsi ini penulis akan membahas secara spesifik konteksi strategi pemasaran dalam kaitannya dengan pengaruh kualitas pelayanan, kualitas produk, kepuasan pelanggan terhadap retensi pelanggan Roti Bakar 88.

Persaingan global menunjuk setiap perusahaan untuk dapat meningkatkan kualitas pelayanan dan kualitas produk yang nantinya akan berpengaruh pada kepuasan pelanggan (customer satisfaction) demi terwujudnya retensi pelanggan (customer retention). Kualitas pelayanan memiliki hubungan yang erat dengan pelanggan, penilaian masyarakat tersebut memaknai produk atau kualitas pelayanan yang di terima. Memberikan pelayanan yang baik akan menghasilkan dorongan kepada pelanggan untuk menjalin ikatan hubungan yang erat dengan pelaku usaha, dalam jangka panjang pelaku usaha akan berusaha untuk memahami dengan harapan saksama harapan pelanggan serta kebutuhan apa yang mereka harapkan.

Dilihat dari sudut pandang pelanggan kualitas produk seringkali diartikan sebagai tolak ukur kepuasan pelanggan, perusahaan harus selalu melakukan upaya untuk mempertahankan pelanggan. Hal ini dapat dilakukan dengan meningkatkan mutu dan kualitas produk, menjaga hubungan yang baik atau komunikasi dengan pelanggan, mendengar, menampung saran atau keluhan dari pelanggan guna mempertahankan pelanggan agar tidak beralih ke produk lain yang sejenis yang di hasilkan perusahaan pesaing. Kepuasan pelanggan merupakan awal menciptakan retensi pelanggan atau mempertahankan pelanggan. Kepuasan pelanggan juga salah satu hal yang harus diperhatikan, jika pelanggan telah memiliki perasaan puas akan pelayanan yang diberikan dapat dipastikan pelanggan akan menjadi pelanggan yang setia dan tidak akan berpaling pada jasa layanan yang lain. Akhir-akhir ini kepuasan pelanggan di rasa mulai menurun, dengan banyaknya usaha rumah makan yang menjamur dengan dan menawarkan konsep baru sehingga secara tidak langsung berimbas kepada selektifnya pelanggan dalam menentukan keputusan untuk melakukan pembelian ulang. Penjualan Roti Bakar 88 Pasar Lama Tangerang mengalami penurunan dari tahun sebelumnya di tahun 2017 sebesar Rp 2.956.200.000 ke tahun 2018 sebesar Rp 2.703.750.000 dengan selisih sebsesar Rp 252.450 .000

Penjualan Roti Bakar 88 yang mengalami penurunan di indikasikan adanya fluktuasi retensi pelanggan yaitu adanya pelanggan tidak melakukan pembelian ulang. Pelanggan dari Roti Bakar 88 merupakan pelanggan yang biasanya selalu kembali untuk makan dan saling bersosialisasi (returning customers). Sehingga dengan adanya penurunan ini, maka dapat dikatakan terdapat permasalahan penurunan keterikatan pelanggan (customer retention) terhadap pelanggan Roti Bakar 88. 


\section{Pengertian Kualitas Pelayanan}

Menurut Parasuraman (2013:23) "Kualitas pelayanan yaitu seberapa jauh perbedaan antara kenyataan dan harapan pelanggan atas pelayanan yang mereka terima". Menurut Parasuraman (dalam A.Rauf $\mathrm{dkk}, 2016: 22$ ) ada dua faktor utama yang mempengaruihi kualitas pelayanan yaitu : Expected service and Perceived service. Apabila jasa yang di terima atau di rasakan lebih menyenangkan di bandingkan harapannya, maka akan menimbulkan kepuasan, sebaliknya apabila jasa yang yang diterima atau di rasakan kurang dari harapan, bahwa di katakan kualitas pelayanan kurang bisa memuaskan pelanggan.

\section{Pengertian Kualitas Produk}

Menurut Rauf dan Yulizar (2016:I) mengemukakan bahwa "Kualitas produk adalah segala sesuatu yang di tawarkan ke pasar untuk mendapatkan perhatian, dibeli, dipergunakan, dan dapat memuaskan kebutuhan pelanggan".

\section{Pengertian Kepuasan Pelanggan}

Menurut Kotler dan Keller (2016:153) “Kepuasan pelanggan adalah pelanggan dapat mengalami salah satu arti tingkat kepuasan umum yaitu jika kinerja di bawah harapan, pelanggan akan merasakan kecewa tetapi jika kinerja sesuai dengan harapan pelanggan akan merasa puas apabila kinerja bisa melebihi harapan maka pelanggan akan merasa puas dan gembira".

\section{Pengertian Retensi Pelanggan}

Salah satu metode pemasaran yang sering digunakan untuk meningkatkan kinerja perusahaannya adalah retensi pelanggan. Dengan mempertahankan pelanggan yang sudah ada tentunya akan menghemat biaya, dari pada dengan mencari lagi pelanggan baru. Konsep retensi pelanggan muncul karena banyak perusahaan yang cenderung mengabaikan pelanggan yang sudah ada dan lebih memprioritaskan melakukan progam akuisisi pada pencarian pelanggan baru. Padahal setelah, dilakukan sejumlah kajian, biaya mendapatkan pelanggan baru lebih tinggi dari pada biaya yang yang dilakukan untuk mempertahankan pelanggan lama atau pelanggan yang sudah ada.

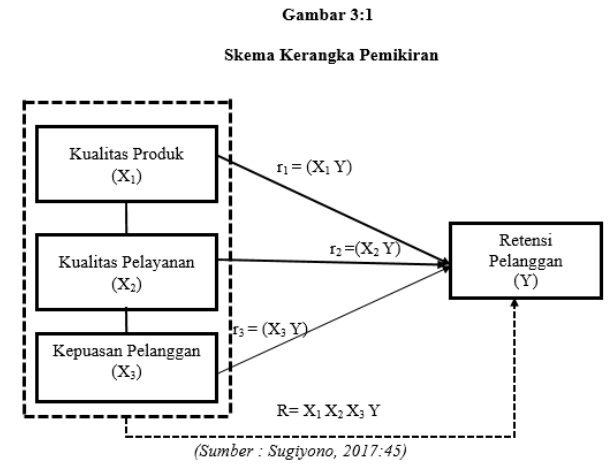

Menurut Alfansi (2016:244) mengatakan retensi pelanggan adalah "upaya mempertahankan pelanggan bagian penting dalam pembangungan pemasaran berbasis hubungan". Bagi sebuah perusahaan mereka tidak hanya menginginkan pelanggan baru namun mereka juga perlu mempertahankan pelanggan sebab hal tersebut dapat meningkatkan bisnis.

\section{Hipotesis}

Gambar I : Kerangka Pemikiran

$\mathrm{Hal}=$ Terdapat pengaruh positif dan signifikan antara kualitas produk terhadap retensi pelanggan pada Roti Bakar 88.

$\mathrm{Ha} 2=$ Terdapat pengaruh positif dan signifikan antara kualitas produk terhadap retensi pelanggan pada Roti Bakar 88.

$\mathrm{Ha} 3=$ Terdapat pengaruh positif dan signifikan antara kualitas produk terhadap retensi pelanggan pada Roti Bakar 88.

$\mathrm{Ha} 4$ = Terdapat pengaruh positif dan signifikan antara kualitas pelayanan, kualitas produk, dan kepuasan pelanggan terhadap retensi pelanggan pada Roti Bakar 88. 
Hol = Tidak terdapat pengaruh positif dan signifikan antara kualitas pelayanan terhadap retensi pelanggan pada Roti Bakar 88.

Ho2 = Tidak terdapat pengaruh positif dan signifikan antara kualitas produk terhadap retensi pelanggan pada Roti Bakar 88.

Ho3 = Tidak terdapat pengaruh positif dan signifikan antara kualitas produk terhadap retensi pelanggan pada Roti Bakar 88.

Ho4 = Tidak terdapat pengaruh positif dan signifikan antara kualitas pelayanan, kualitas produk, dan kepuasan pelanggan terhadap retensi pelanggan pada Roti Bakar 88.

\section{B. METODE PENELITIAN}

Penelitian ini merupakan penelitian kausal untuk mengetahui adanya hubungan yang bersifat mempengaruhi antara dua variabel atau lebih dengan pendekatan kuantitatif Metode penelitian yang digunakan dalam penelitian ini adalah metode survey yaitu penelitian dilakukan dengan terjun langsung ke lapangan dengan menyebar angket atau kuisioner sebagai instrumen pengumpulan data.

\section{Populasi}

\section{Sampel}

Populasi dalam penelitian ini adalah pelanggan Roti Bakar 88 Pasar Lama Tangerang.

Sampel dalam penelitian ini adalah pelanggan Roti Bakar 88 Pasar Lama Kota Tangerang karena pada penelitian ini sangat besar populasinya dan tidak dapat diketahui secara pasti keseluruhan berapa banyak jumlahnya, oleh karena itu akan sulit mencari berapa jumlah populasi yang tepat, maka jumlah sampel yang digunakan dalam penelitian ini menggunakan rumus Uma Sekaran. Dimana tingkat keyakinan yang di pakai dalam penelitian yaitu $90 \%$ dengan penentuan $Z$ pada $\alpha: 0,10$ adalah 1,98 . Sehingga jumlah sampel dalam penelitian ini sebanyak 100 responden.

\section{Teknik dan Pengambilan Sampel}

Dalam penelitian ini teknik pengambilan sample yang digunakan dalam adalah Probability sampling, yaitu teknik pemilihan berdasarkan probabilitas (peluang) acak. Sedangkan metode yang digunakan adalah teknik pengambilan sampel sederhana (simple random sampling) dalam teknik pemilihan sampel yang memberikan peluang atau kesempatan yang sama pada populasi untuk dijadikan subjek penelitian.

\section{Metode Analisa Data}

\section{Uji Validitas}

Menurut Andra Tersiana (2017:121) "uji validitas merupakan alat ukur yang digunakan untuk mendapatkan data (mengukur) itu valid". Suatu alat ukur yang validitasnya tinggi akan mempunyai varian kesalahan yang kecil atau dengan kata lain test tersebut menjalankan ukurannya dengan memberikan hasil yang sesuai dengan maksud test tersebut.

\section{Uji Reabilitas}

Realibilitas (konsisten) digunakan untuk mengetahui konsisten tidaknya instrumen yang dipakai.

\section{Uji Asumsi Klasik}

I. Uji Normalitas

Menurut Ghozali (2018:45) Uji normalitas bertujuan untuk menguji apakah dalam model regresi, variabel terikat dan variabel bebas keduanya mempunyai distribusi normal atau tidak".

2. Uji Multikolinearitas

Menurut Ghozali (2016:103) Uji multikolinearitas bertujuan "untuk menguji apakah model regresi ditemukan adanya korelasi antar variabel independen". Model regresi yang baik seharusnya tidak terjadi korelasi sempurna atau mendekati sempurna di antara variabel bebasnya.

3. Uji Heteroskedastisitas

Menurut Syaiful Bahri (2018:180) “Uji heteroskedatisitas adalah varian residual yang tidak sama pada semua pengamatan di dalam model regresi. Model regresi yang baik seharusnya tidak terjadi heteroskedastisitas

\section{Analisis Regresi Berganda}

Analisis Regresi Berganda merupakan analisis yang menghubungkan antara dua variabel independen atau lebih dengan variabel dependen. 


\section{Analisis Korelasi Berganda}

Analisis ini bertujuan untuk mengetahui seberapa besar hubungan ketiga variabel bebas terhadap variabel terikat dengan menggunakan koefisien korelasi ganda adalah dengan menggunakan nilai absolut dari koefisien korelasi tersebut.

\section{Uji Hipotesis}

I. Uji Statistik T

Untuk statistik $\mathrm{t}$ digunakan untuk pengujian hipotesis pengaruh variabel independen secara individu terrhadap variabel dependen.

2. Uji Statistik F

Uji statistik $F$ digunakan untuk pengujian hipotesis semua variabel independen yang dimasukkan dalam model berpengaruh secara bersama-sama terhadap variabel dependen dan juga untuk menentukan model kelayakan model regresi.

\section{Koefisien Determinasi}

Analisis koefisien determinasi digunakan untuk mengukur kemampuan model dalam menerangkan variasi variabel independen terhadap variabel dependen atau dapat pula di katakan sebagai proporsi pengaruh seluruh variabel independen terhadap variabel dependen.

\section{HASIL PEMBAHASAN}

I. Uji Normalitas
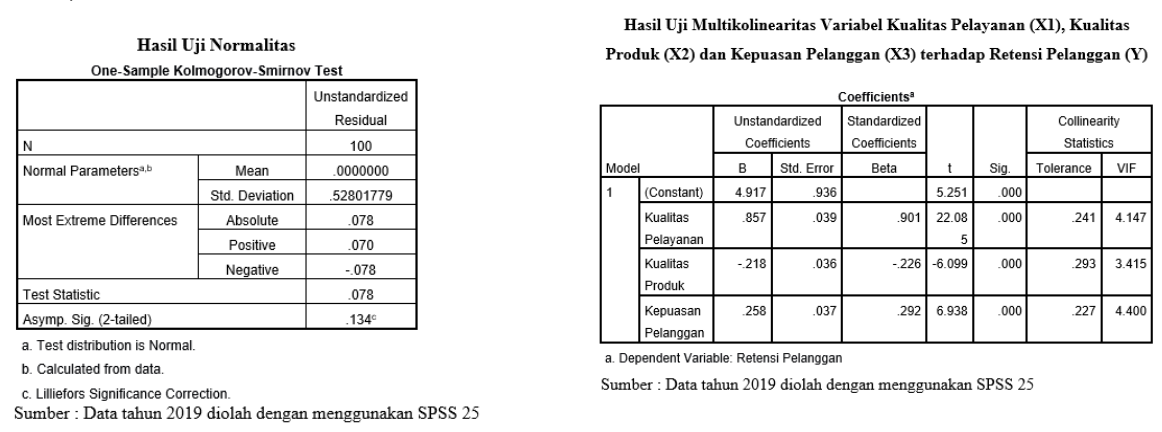

Sumber : Data tahun 2019 diolah dengan menggunakan SPSS 25

Hasil perhitungan tabel one-sample kolmogorov-smirnov test menunjukkan nilai test statistic sebesar 0,78 dengan tingkat signifikasi sebesar 0,134. Pada tabel tersebut nilai signifikasi 0,134>0,05 maka dapat disimpulkan data berdistribusi normal.

\section{Uji Multikolinearitas}

Pada table coefficients di atas dapat diketahui bahwa nilai VIF variabel kualitas pelayanan sebesar 4.I47, nilai VIF variabel kualitas produk sebesar 3.415 sedangkan untuk variabel kepuasan pelanggan nilai VIF sebesaar 4.400. Nilai VIF ketiga variabel tersebut $<10$ atau tidak ada variabel bebas yang memiliki Variance Inflation Factor (VIF) di atas 10 sehingga disimpulkan tidak terjadi multikolinearitas antar variabel bebas dalam model regresi yang digunakan. Untuk melihat gejala multikonlinearitas juga dapat dilihat pada nilai tolerance bila hasil perhitungan nilai tolerance mendekati I, maka model tersebut bebas dari gejala mulitkolinearitas. Tabel coefficients masing - masing niilai tolerance dari variabel bebas mendekati angka satu sehingga tidak terindikasi gejala multikolinieritas.

3. Uji Heteroskedastisitas 


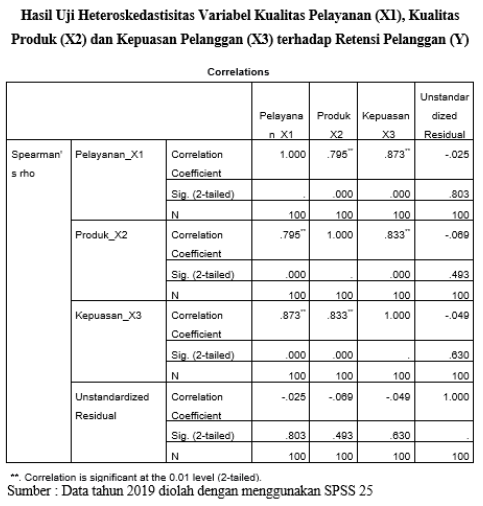

Hasil perhitungan tabel correlations menunjukkan korelasi antara variabel kualitas pelayanan dengan nilai unstandardized residual memiliki nilai signifikasi lebih dari 0,05 tingkat signifikasi sebesar 0,803 > 0,5 . Korelasi antara variabel kualitas produk dengan nilai unstandardized residual memiliki nilai signifikasi lebih dari 0,05 tingkat signifikasi sebesar 0,493 $>0,05$. Korelasi variabel kepuasan pelanggan dengan unstandardized residual nilai signifikasi sebesar lebih dari 0,05 tingkat signifikasi

4. Uji Regresi Linier Berganda

Hasil Uji regresi linier berganda pada table coefficents menunjukkan nilai konstanta a dan koefisien b, selanjutnya nilai tersebut dapat di hitung ke dalam rumus di bawah ini :

$Y=4.917+0,857 \times 1+-0,218 \times 2+0,258 \times 3$

Dimana

$Y=$ Retensi Pelanggan

$X_{1}=$ Kualitas Pelayanan

$\mathrm{X}_{2}=$ Kualitas Produk

$\mathrm{X}_{3}=$ Kepuasan Pelanggan

- Konstanta sebesar 4,917 artinya jika Kualitas Pelayanan, Kualitas Produk dan Kepuasan Pelanggan nilainya 0 , maka retensi pelanggan sebesar 4,917

- Koefisien regresi variabel Kualitas Pelayanan sebesar 0,857, artinya jika kualtas pelayanan meningkat sebesar satu satuan, maka retensi pelanggan akan meningkat sebesar 0,857 satuan dengan asumsi variabel independen lain bernilai tetap.

- Koefisien regresi variabel Kualitas Produk sebesar -0,218 artinya jika kualitas produk menurun sebesar satu satuan, maka retensi pelanggan akan menurun sebesar 0,2 I 8 satuan dengan asumsi variabel independen lain bernilai tetap.

- Koefisien regresi variabel Kepuasan Pelanggan sebesar 0,258 meningkat sebesar satu satuan maka retensi pelanggan akan meningkat sebesar 0,258 satuan dengan asumsi variabel independen lain bernilai tetap.

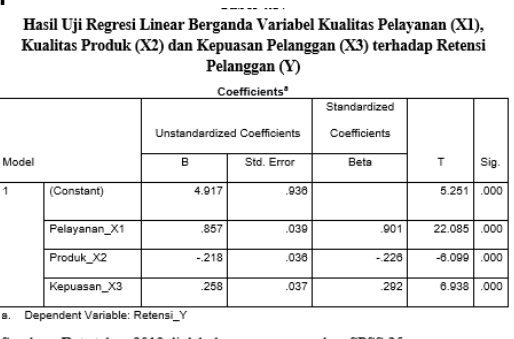

Sumber : Data tahun 2019 diolah dengan menggunakan SPSS 25

5. Uji Korelasi Berganda 
Hasil Uji Koefisen Korelasi Variabel Kualitas Pelayanan (X1), Kualitas Produk (X2) dan Kepuasan Pelanggan (X3) terhadap Retensi Pelanggan

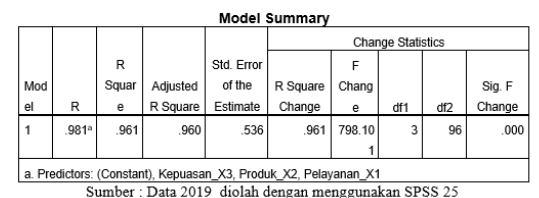

Hasil perhitungan tabel uji koefisien korelasi berganda maka diketahui bahwa nilai Sig. $F$ change $<0,05$ yaitu $0,000<0,05$ yang menunjukkan bahwa variabel independen $(X)$ memiliki hubungan korelasi terhadap variabel terikat dengan nilai $R=0,98 \mathrm{I}$ atau $(98,1 \%)$ artinnya kualitas pelayanan, kualitas produk, kepuasan pelanggan terhadap retensi pelanggan menujukkan korelasi positif dan sangat kuat karena nilai korelasi berada di range 0,80-I.000. Nilai korelasi positif artinya terjadi hubungan positif yaitu jika kualitas pelayanan, kualitas produk, kepuasan pelanggan meningkat maka retensi pelanggan juga semakin tinggi.

\section{Uji Statistik T}

\section{Variabel Kualitas Pelayanan terhadap Retensi Pelanggan}

Hasil Uji statistik t Variabel Kualitas Pelayanan terhadap Retensi Pelanggan

(Y)

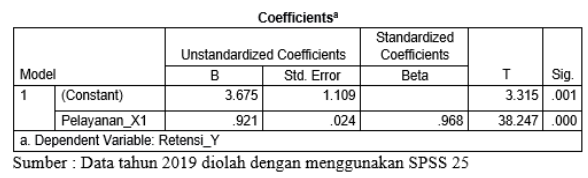

Hasil perhitungan tabel uji statistik $\mathrm{t}$ variabel $\mathrm{XI}$ dengan $\mathrm{Y}$ thitung $=38.247$ yang menggunakan taraf kesalahan $5 \%$ diperoleh ttabel $=1,983$ jadi thitung $>$ ttabel $(38.247>1,983)$. Maka Ho ditolak dan $\mathrm{Ha}$ diterima, artinya terdapat pengaruh yang positif dan signifikan antara kualitas pelayanan terhadap retensi pelanggan.

Variabel Kualitas Produk terhadap Retensi Pelanggan

Hasil Uji statistik t Variabel Kualitas Produk terhadap Retensi Pelanggan

(Y)

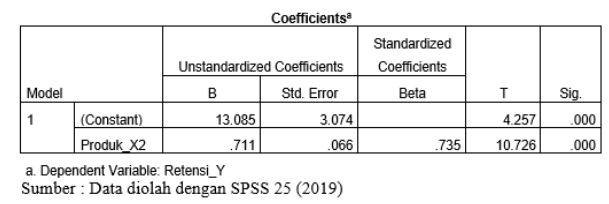

Hasil perhitungan tabel uji statistik $t$ variabel $X 2$ dengan $Y$ thitung $=10.726$ yang menggunakan taraf kesalahan $5 \%$ diperoleh ttabel $=1,983$ jadi thitung $>$ ttabel $(10.726>1,983)$. Maka Ho ditolak dan $\mathrm{Ha}$ diterima, artinya terdapat pengaruh yang positif dan signifikan antara kualitas pelayanan terhadap retensi pelanggan. 


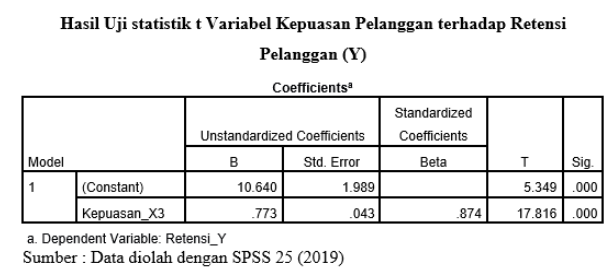

Hasil perhitungan tabel uji statistik $t$ variabel $X 3$ dengan $Y 4.61$ thitung $=17.816$ yang menggunakan taraf kesalahan $5 \%$ diperoleh ttabel $=1,983$ jadi thitung $>$ ttabel $(17.816>1,983)$. Maka Ho ditolak dan $\mathrm{Ha}$ diterima, artinya terdapat pengaruh yang positif dan signifikan antara kualitas pelayanan terhadap retensi pelanggan.

7. Uji F Pengaruh Simultan (Uji Statistik F)

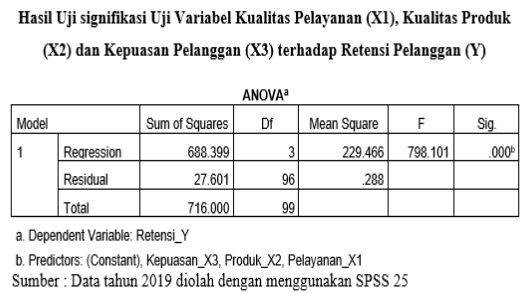

Dari hasil perhitungan uji statistik $\mathrm{F}$ diatas diperoleh Fhitung 798.10I dibandingkan dengan $\mathrm{F}$ tabel 3,09 berdasarkan perbandingan tersebut di ketahui bahwa nilai Fhitung >Ftabel yaitu 798.10I > 3,09 oleh sebab itu maka Ho ditolak dan Ha diterima bahwa model regresi dapat digunakan untuk memprediksi retensi pelanggan. Atau dapat dikatakan bahwa kualitas pelayanan, kualitas produk dan

\section{Koefisien Determinasi}

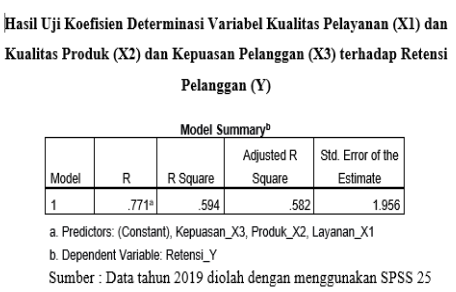

Hasil perhitungan pada tabel uji koefisien determinasi diketahui bahwa R Square = 0,594 (59,4\%) artinya pengaruh kualitas pelayanan (XI), kualitas produk $(X 2)$ dan kepuasan pelanggan adalah sebesar $(59,4 \%)$ dan sisanya $(40,6 \%)$ dipengaruhi oleh faktor lain atau variabel lain.

\section{KESIMPULAN DAN SARAN}

Kesimpulan pada hasil penelitian ini sebagai berikut :

I. Hasil uji t pada variabel kualitas pelayanan yang digunakan oleh Roti Bakar 88 Pasar Lama Tangerang secara parsial berpengaruh positif dan signifikan terhadap retensi pelanggan. Hal ini di 
tunjukkan oleh nilai $t_{\text {hitung }}>t_{\text {tabel }}$ yaitu 38,247 $>1,983$ dan memiliki nilai signifikasi sebesar 0,000 nilai ini lebih kecil dari $0,05(0,000<0,05)$ maka berarti Ho ditolak dan Ha di terima.

2. Hasil uji t pada variabel kualitas produk yang digunakan oleh Roti Bakar 88 Pasar Lama Tangerang secara parsial berpengaruh positif dan signifikan terhadap retensi pelanggan. Hal ini di tunjukkan oleh nilai $t_{\text {hitung }}>t_{\text {tabel }}$ yaitu $10,726>1,983$ dan memiliki nilai signifikasi sebesar 0,000 nilai ini lebih kecil dari $0,05(0,000<0,05)$ maka berarti Ho ditolak dan Ha di terima.

3. Hasil uji $\mathrm{t}$ pada variabel kepuasan pelanggan produk yang digunakan oleh Roti Bakar 88 Pasar Lama Tangerang secara parsial berpengaruh positif dan signifikan terhadap retensi pelanggan. $\mathrm{Hal}$ ini di tunjukkan oleh nilai $h t_{\text {hitung }}>t_{\text {tabel }}$ yaitu $(17,816>1,983)$ dan memiliki nilai signifikasi sebesar 0,000 nilai ini lebih kecil dari $0,05(0,000<0,05)$ maka berarti Ho ditolak dan $\mathrm{Ha}$ di terima.

4. Hasil Uji $F$ terdapat pengaruh secara simultan antara kualitas pelayanan, kualitas produk, kepuasan pelanggan dan retensi pelanggan dibuktikan dengan menunjukkan bahwa $F_{\text {hitung }} 789,|0|>F_{\text {tabel }}>$ 3,09 dengan tingkat signifikansi sebesar $0,000<0,05$ yang berarti signifikan. Dengan demikian Ho ditolak dan Ha diterima.

5. Analisa perhitungan koefisien determinasi adalah 0,594 menunjukkan kuat nya pengaruh variabel kualitas pelayanan, kualitas produk dan kepuasan pelanggan terhadap retensi pelanggan adalah 59,4 $\%$ adapun sisa nya sebesar $40,6 \%$ dipengaruhi oleh faktor lain yang tidak di teliti.

\section{Saran}

Untuk menjamin kesimpulan - kesimpulan sebagai mana telah di kemukakan di atas yang saling berkaitan maka dengan ini penulis memberikan saran - saran sebagi berikut :

I. Hasil dari kualitas pelayanan sangat signifikan maka kepada pimpinan perusahaan penulis menyarankan agar selalu memotivasi dan memberi teladan-teladan yang baik dalam komunikasi kepada seluruh karyawan terutama yang berkaitan dengan calon konsumen/pelanggan sehingga peningkatan kualitas pelayanan untuk memberi kepuasan kepada pelanggan lebih efisien dan efektif sesuai dengan kebutuhan para pelanggan.

2. Begitu pula dengan kualitas produk sangat signifikan maka kepada pimpinan perusahaan penulis menyarankan agar cita rasa makanan lebih di tingkatkan lagi serta adanya penambahan variasi dalam menu sehingga pelanggan selalu ingin berkunjung kembali dengan adanya peningkatan dalam segi produk.

3. Hasil kepuasan pelanggan yang sangat signifikan diharapkan pimpinan perusahaan harus lebih memonitoring kepuasan pelanggan untuk menjaga agar para pelanggan selalu setia dan tidak berpindah ke rumah makan lain.

4. Sesuai dengan hasil uji $F$, pengaruh simultan antara variabel-variabel pada judul skripsi penulis dinyatakan dapat diterima, maka penulis menyarankan agar di samping memotivasi para karyawan secara teratur dan baik perlu juga di terapkan loyalty program kepada pelanggan memberikan penawaran yang menaik seperti potongan harga, voucher gratis atau mengadakan member card bagi para pelanggan yang sering melakukan transaksi di Roti Bakar 88 Pasar Lama Tangerang.

5. Sehubungan dengan hasil perhitungan koefisien deterrminasi menunjukkan bahwa pengaruh simultan yang kuat, maka kepada pimpinan perusahaan penulis menyarankan agar kondisi yang telah baik ini kiranya perlu di tindak lanjuti dengan memaksimalkan dan memperbaiki kinerja karyawan, mengevaluasi kualitas produk dan lebih memperhatikan kebutuhan pelanggan agar pelanggan selalu merasa puas sehingga akan selalu berkunjung kembali ke Roti Bakar 88 Pasar Lama Tangerang.

\section{E. DAFTAR PUSTAKA}

Bahri Syaiful (20I8) "Metodelogi Penelitian Bisnis - Lengkap dengan Teknik Pengolahan data SPSS" CV Andi Offset, Yogyakarta.

Ghozali (2018) “Aplikasi Analisis Multivariate dengan Program IBM SPSS 25” Edward Edgar Publishing Limited, Yogyakarta.

Kasmir (2016) “Kewirausahaan” Rajawali Pers, Jakarta. 
Kotler, Philip dan Keller, Kevin Lane (2012) “Manajemen Pemasaran” jilid I Edisi ke 23 Erlangga, Jakarta.

Lupiyoadi (20/3) "Manajemen Pemasaran Jasa” Salemba Empat, Jakarta.

Nasution Muhammad Nur (20I5) “Manajemen Mutu Terpadu” Edisi ke-3 Ghalia Indonesia, Bogor.

Noor Juliansyah (2015) "Metode Penelitian Skripsi, Tesis, Disertasi, dan Karya Ilmiah" Prenadamedia, Jakarta.

Over Mexi \& Ratna Juwita (2017) "Pengaruh Kualitas Pelayanan, Kepuasan Pelanggan, Kualitas Produk dan Relationship Marketing (Studi Kasus Pelanggan Kopi Pulang Palembang)”.

Rauf, Abdul dan Ismayudin Yulizer (2016) “Manajemen Pemasaran” CV Artika Nawala, Jakarta

Sangadji, Etta Mamang, dkk (20I3) "Perilaku Konsumen” ANDI, Yogyakarta.

Sudaryono (2018) “Metodelogi Penelitian” Raja Grafindo, Jakarta.

Sugiyono (2015) "Statistika untuk Penelitian" Alfabeta, Bandung.

Sugiyono (2017) “Metode Penelitian Kuantitatif Dan Kualitatif Dan R\&D” Alfa Beta, Bandung.

Sunyoto Danang (2014) “Konsep Dasar Riset Pemasaran dan Perilaku Konsumen” Edisi ke 2, CAPS, Yogyakarta.

Tersiana Andra (2018) “Metode Penelitian” Start Up, Yogyakarta

Tjiptono Fandy,dkk (2017) "Pemasaran Strategik” ANDI, Yogyakarta. 